\title{
"After Haeckel": An Exhibition of Microscopic Primitive Life Forms
}

\author{
"L'après Haeckel » : une exposition de formes de vie primitives \\ microscopiques
}

\author{
John R. Dolan ${ }^{1}$ \\ ${ }^{1}$ Sorbonne Université CNRS, Laboratoire d'Océanographie de Villefranche-sur-Mer, Station Zoologique, B.P. 28, \\ 06230 Villefranche-sur-Mer, France, dolan@obs-vlfr.fr
}

\begin{abstract}
Ernst Haeckel, the German naturalist, in 1868 depicted amoeboid microorganisms as primordial life forms. He claimed they were without nuclei or cell membranes but capable of feeding and reproducing. He called such organisms Moners. His remarkable illustrations of the presumably primordial life forms were very widely reproduced in both the scientific and popular press. By 1915 the primitive nature of the organisms and even their existence were in disrepute as no such organisms were found by anyone else. Today, they are largely forgotten. Here the remarkable variety of images of Haeckel's primordial Protomyxa, published from 1868 to 1913, are presented. Examination of Haeckel's original illustrations and the subsequent adaptations by others, provide insights into what was, and might still be, thought to be primitive. In the adaptations, the primordial life forms were most commonly shown with the remains of prey inside them and capturing a prey organism. The portrayals of primitive microorganisms as predatory and aggressive, mirrors portrayals of dinosaurs and primitive humans.

KEYWORDS. scientific illustration, portrayals of primitive life, 19th century science, history of science.
\end{abstract}

\section{Introduction}

\subsection{The Historical Context - The Search for Origins}

Charles Darwin's "On the Origin of the Species" appeared in 1859. It provided an explanation of how organisms changed with time, that is how one species eventually gave rise to another species and thus how different species could be related to one another. It left open, and brought renewed interest in, how life began and in what form. The theory of spontaneous generation, that posits life forms now known (e.g., flies, protists, bacteria) could arise out of non-living matter, was largely discredited through careful experimentation by Louis Pasteur (1861). However, Thomas Huxley (1870) made the argument that, unless one accepts divine intervention, life somehow did begin and perhaps simple living matter could arise out of non-living matter under conditions unknown or unexamined at present. He called such a formation of life from non-living matter 'abiogenesis' (e.g., Huxley 1870). Huxley's arguments were in self-defense as he had recently described Bathybius heackelii, a supposed primitive microscopic life form. It was, Huxley thought, an amorphous mass of protoplasm with no structure or nucleus that he had found in a preserved sample of mud from the deep-sea (Huxley 1868). At that time, the deep-sea was a completely unexplored, unknown, zone thought by some to be lifeless (e.g. Forbes \& Goodwin-Austin 1859). Huxley named his discovery from the deep-sea for Ernst Haeckel as

"... a new form of those simple animated beings which have recently been so well described by Haeckel in his 'Monographie der Monern'. I propose to confer upon this new 'Moner', the generic name of Bathybius, and to call it after the eminent Professor of Zoology in the University of Jena, B. Haeckelii."

Scientific hypotheses other than Huxley's "abiogenesis" were proposed for the origin of life on earth, such as seeding from other planets via meteors (e.g. Thomson 1872). However, with regard to 
primitive life forms, only Haeckel purported to have seen and describe things resembling primordial life forms, as Huxley's dedication of Bathybius implied.

\subsection{Haeckel's Moners - An Origins Candidate}

Among the defenders of Darwin, if Huxley would be called "Darwin's Bull-Dog" among the English-speaking, Haeckel could have been "Darwin's Doberman" among the German-speakers. He was one of the first of his proponents in Germany. In a widely-distributed essay he wrote about Darwin's theory and specifically how Darwin's theory of the relatedness of species allowed examination of how all living organisms were related to each other (Haeckel 1863). Haeckel stated that the relationships among species, once revealed, would permit construction of a complete phylogeny of life, which could be represented as a tree with all organisms ultimately derived from 'a few or a single form, perhaps spontaneously created, original form' (Haeckel 1863, pg. 20). Darwin greatly appreciated Haeckel's essay, writing to him in March 1864 (Darwin Correspondence Project 2020a):

"I am delighted that so distinguished a Naturalist should confirm \& expound my views, and I can clearly see that you are one of the few who clearly understand Natural Selection."

Shortly after his essay, Haeckel published an article that lambasted at length the opinions of one Carl B. Reichert, a Berlin professor of anatomy, concerning the nature of protoplasm (Haeckel 1865). Reichert had earlier published an article saying that all the previous observations of particle transport inside cells in the protoplasm and movement of protoplasm were artifacts; protoplasm was not dynamic and always was contained in a cell membrane (Reichert 1863). Consequently, following Reichert, everyone before him had been wrong concerning the nature of protoplasm, including Haeckel's mentor Johannes Müller, and Félix Dujardin, the classic first describer of gelatinous cell contents, of what we now call protoplasm. Dujardin described material found as cellular matrix when the cell is broken open as "sarcode"; he described it as homogenous material, elastic or contractile, diaphanous, refractive more than water but less than oil with no trace of organization (Dujardin 1841). Thus, it was generally recognized as contractile. In addition, Reichert had ignored Haeckel's own work including his highly acclaimed radiolarian monograph (Haeckel 1862) with many observations on the nature of protoplasm through his detailed description of how the microscopic radiolaria feed, capturing and ensnaring prey with fine filaments of protoplasm.

In the 1865 article, Haeckel bolstered his arguments concerning the nature of protoplasm by describing an organism he had observed in Villefranche (near Nice, France) during a stay in 1864. He described it as the most primitive life form observed, composed only of a mass of protoplasm which fed and reproduced by division. He named the creature Protogenes primordialis. In the new form he had found, Haeckel saw not only evidence to refute Reichert but more importantly, what he thought to be something like the original life-form. He wrote to Darwin in November of 1865 saying (Darwin Correspondence Project 2020b):

"Among the new Rhizopoda of Nice the "Protogenes primordialis" (fig. 1, 2) ${ }^{1}$ might interest you as one of the simplest of all creatures, an organism without organs, homogeneous throughout! The generatio aequivoca ${ }^{2}$ of such a living gelatinous mass is at any rate conceivable, and this would help the theory of descent with the difficulty of explaining the first origin ${ }^{3}$."

\footnotetext{
${ }^{1}$ refers to the plate in Haeckel 1865 shown here as Fig 1 below.

${ }^{2}$ refers to spontaneous generation or the abiogenesis of Huxley

${ }^{3}$ the origin of life
} 


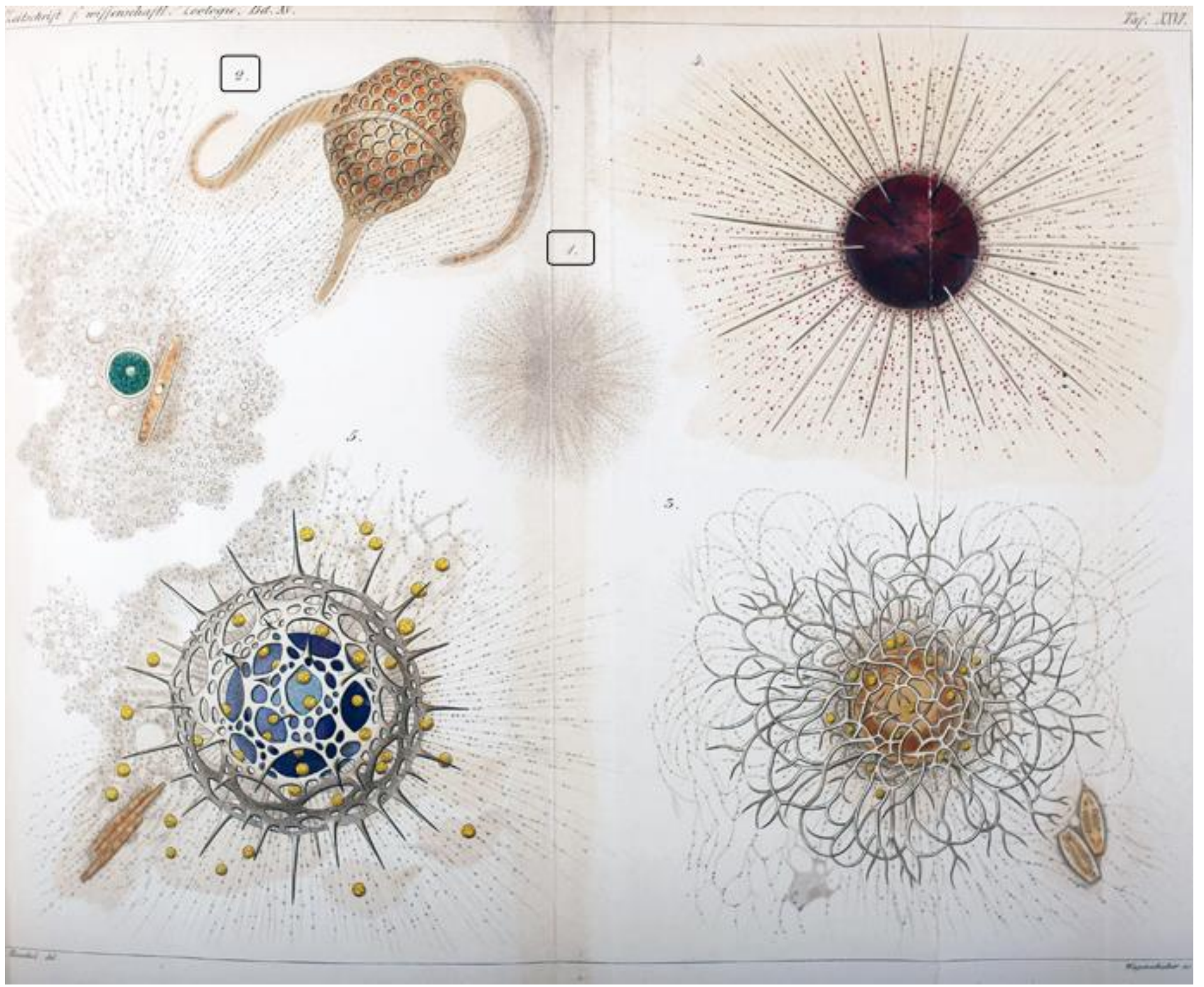

Figure 1. The plate from Haeckel 1865. Figures 1 and 2 (numbers in squares) show different life stages of Protogenes primordialis. Fig. 1, in the center of the plate, shows the spherical stage with fine filaments of protoplasm radiating outward. Fig. 2, in the upper left corner, shows the feeding stage- an amorphous mass containing captured prey (the green ball and brown bar-shaped items) and filaments of protoplasm radiating up and out ensnaring the large brown prey item. Figures 3, 4, and 5 show species of radiolarians, singlecelled organisms with intricate, elaborate, skeletons or shells in contrast to the featureless Protogenes. The radiolarians shown in Figs. 4 and 5 are shown with prey items caught in their filamentous pseudopods like Protogenes in fig. 2. 
Haeckel soon after actually did present a tree of life with Moners as root organisms and including among them his Protogenes primordialis. The tree of life appeared in a dense 2 volume treatise "General morphology of organisms: General principles of organic science of form, based on the theory of descent formulated by Charles Darwin" (Haeckel 1866). About one page of text was dedicated to Protogenes in the form of a footnote, but it included no illustrations of it or any other Moners. However, not long after, Haeckel published a monograph on Monera with two striking plates showing what he described as Moners (Haeckel 1868). The monograph was translated into English and published in installments (as Haeckel 1869). The translated version included adaptations of the original plates. Two species of Moners were depicted in the plates, Protomyxa aurantiaca and the other Myxastrum radians both found during a stay in the Canary Islands in 1867. Both were shown as organisms with several morphologically distinct life-stages, including 2 stages similar to those of Protogenes primordialis shown in fig. 1, that is a stage of a spherical mass with radiating filaments of protoplasm and another as an amorphous amoeboid mass feeding and containing captured prey items. Although two 'species' were described and shown, Protomyxa was commonly used as an example of a primitive organism. Haeckel's images of Protomyxa as a primitive life-form, and how his images were adapted by others is the subject of this essay.

\subsection{What Follows}

First, Haeckel's Protomyxa plate from his 1868 monograph will be considered along with two other versions that appeared in 1869 and 1873. The later versions, both attributed to Haeckel but one perhaps questionably, will be compared to the 1868 version and the differences examined. Then, the many and varied illustrations of Protomyxa which appeared in articles and books by others, all labeled 'after Haeckel', which appeared from 1869 to 1915 (when the existence of Moners was largely discredited) will be shown. The rise and fall of interest in Protomyxa can be seen in Fig. 2 showing the frequency of the occurrence of the word Protomyxa in books between 1860 and 1920 (books digitized by Google Books). Although the reality of the organism's existence is now thought to be unlikely, the wide varieties of illustrations are of great interest today. A comparison among the different versions allows identification of characteristics that varied among the depictions and, more importantly, those that appeared most commonly. The commonalties among of the images should be those that suggest, directly or indirectly, important characteristics attributed to the primitive.

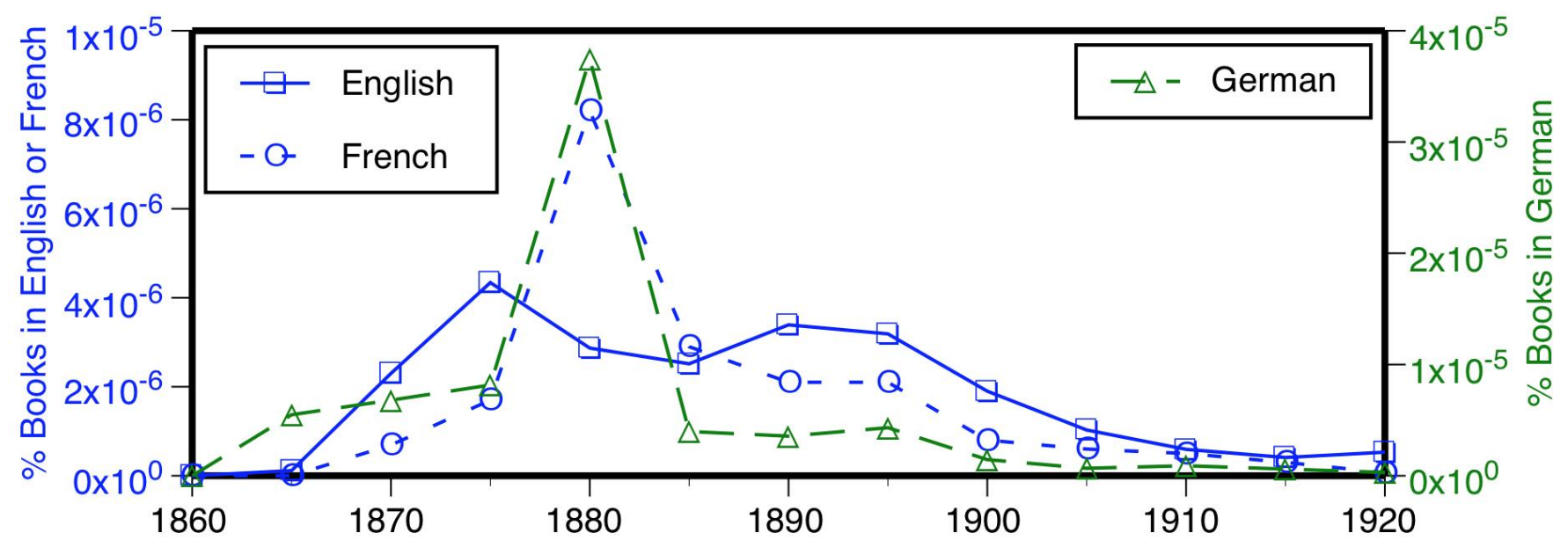

Figure 2. The rise and fall of Protomyxa in books. The frequency of occurrence of the word Protomyxa in books between 1860 and 1920 in English, French, and German books digitized by Google Books. The data are from the "Google NGram viewer", smoothing 5-year averages. Note the similar rapid rise from 1870 to 1880 and subsequent decline to the near absence by 1910 of Protomyxa, in German, English, and French books. 


\section{Haeckel by Haeckel (Mostly)}

The original version of Haeckel's Protomyxa appeared as a foldout plate in his 1828 publication in German (Fig. 3A). The text was translated into English by an entomologist, W. F. Kirby, at the demand of Edward Percival Wright, an Irish naturalist with expertise on invertebrates such as sponges and sea slugs. The translation, was accompanied by 2 plates of illustrations drawn by Tuffen West (fig. 3B shows the Protomyxas plate), and was published in 1869 as authored by Haeckel. Not only the layout but also the figures differ considerably from those of the 1868 Haeckel paper. The plate is labeled at the bottom "E. Haeckel del. Tuffen West sc.". The abbreviation 'del.' denotes the author of a drawing and "sc." the engraver (Stijnman 2012). However, it seems probable that West was actually the author of the drawings. Of all those involved in the presentation of the Protomyxa in English, only the illustrator, Tuffen West, had expertise in microorganisms. West was well known as both an accomplished, expert, illustrator and also as an experienced, trusted, scientific describer of microorganisms (e.g. Quekett 1861). There is no known correspondence between Haeckel and those involved in the translation of the article. In the journal index it is credited to Haeckel alone. It would be reasonable to assume that any differences in the 1869 version of West's 'by Haeckel', were on the part of West rather, than accidental differences, or at the request of Wright or Kirby. The subsequent version of the Protomyxa, by Haeckel himself, also in a single page format (Fig. 3C) first appeared in the 3rd German edition of Haeckel's very popular book 'The Story of Creation' in 1873 and in the later editions up to and including the 9th edition in 1898. It also appeared in the translations of the book into English (1876) and French (1877). Thus, the plate that first appeared in 1873 by Haeckel was probably the most widely available portrayal.

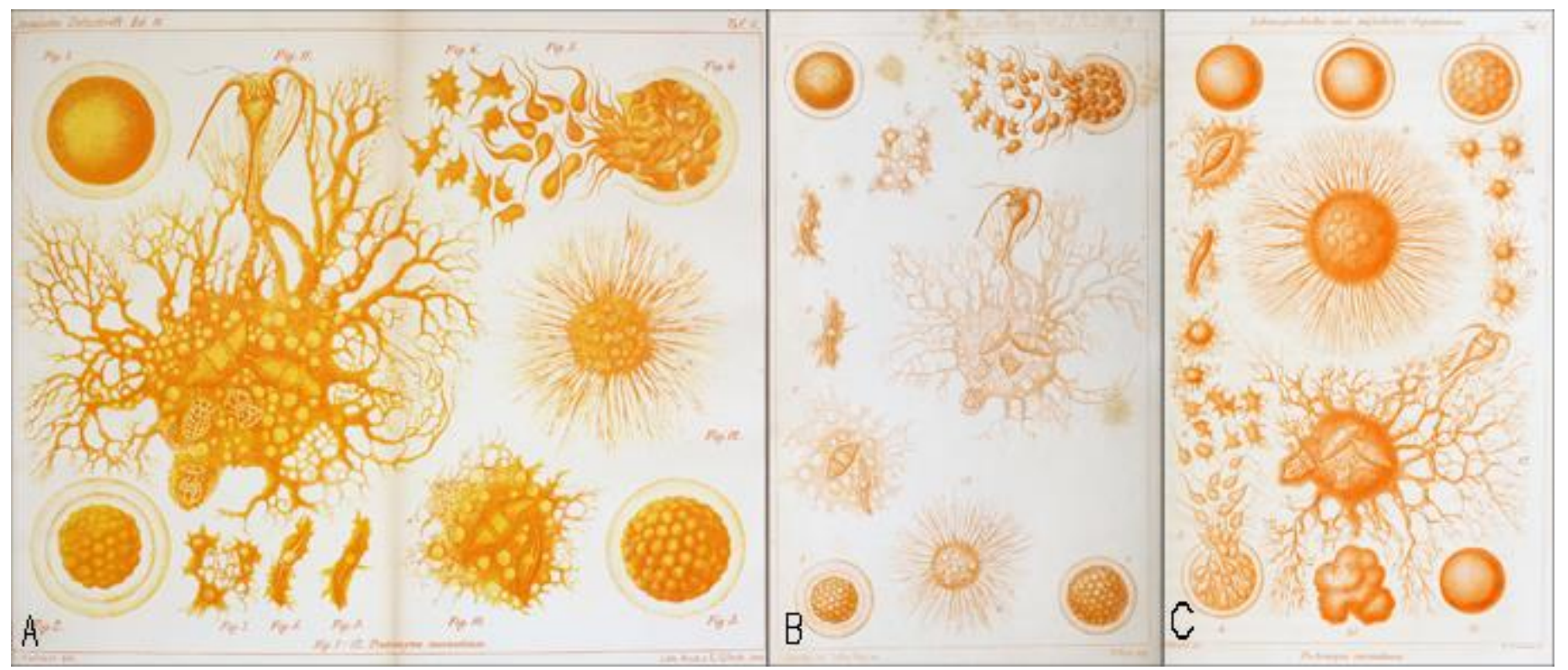

Figure 3. The illustrations of Protomyxa, the primitive life-form, credited to Haeckel: $\boldsymbol{A}$. the fold-out plate from Haeckel's 1868 monograph; the feeding amoeboid stage dominates the plate; it has with an amorphous central mass containing ingested items and a live prey at the top. THe large stage is about 0.5 $\mathrm{mm}$ across. B. The Protomyxa plate of the 1869 English translation of Haeckel's 1868 monograph. Despite the labeling on the plate, probably not only the engraving but also the drawings were by West and not Haeckel; the amoeboid feeding stage and the spherical stage with radiating filaments differ considerably from the 1868 version while the other figures are nearly identical. C. The Protomyxa plate from Haeckel's 3rd edition of "The Story of Creation" in 1873. Note that the spherical stage with radiating filaments is the centerpiece, both it, and the feeding amoeboid stage, differ from the 1868 version. See the text for details. 
There are obvious and interesting differences among the 3 plates showing the various stages Protomyxa. In Haeckel's original 1868 plate (Fig. 3.A) the most prominent stage by far is the feeding amoeboid stage. The figure shows, at the top, a live prey item, the dinoflagellate Ceratium ensnared. The well-known prey item is about 150 microns in length. Thus the entire amoeboid stage is about $0.5 \mathrm{~mm}$ across. In the 'Haeckel adapted by West' version of 1869 (Fig. 3.B), the feeding amoeboid stage is the centerpiece but it is reduced in relative size compared to the other stages and differs in that the central mass of the feeding amoeboid is nearly circular with strands radiating out rather than the amorphous tangled mass in the 1868 original. In Haeckel's 1873 version (Fig. 3.C), the central image is the stage of the spherical mass, and it is more distinctly spherical than in the 1868 version, with fine filaments, finer than in the original, radiating outward; the feeding amoeboid stage is greatly reduced in size relative to the other stages and given a more regular contour similar to that of West's version. In quantitative terms, the total height of the feeding amoeboid stage, relative to that of the spherical mass with filaments, is nearly 1.9 times greater in the original 1868 version, 1.7 times greater in the 1869 West version and only 1.2 times greater in Haeckel's 1873 version. We shall see that the feeding amoeboid stage, while given markedly less prominence in the later illustrations of the primitive Protomyxa attributed to Haeckel, will nonetheless be the most commonly reproduced in the scientific and popular press.

\section{After Haeckel 1869 - 1913}

Protomyxa quickly became widely known, appearing in many books, as shown in figure 2 . To examine how it was portrayed, websites compiling very large numbers of digitized works were used to locate works in open access, with illustrations of Protomyxa. The websites used were: 1) the Biodiversity Heritage Library (https://www.biodiversitylibrary.org/), 2) Gallica (https://gallica.bnf.fr/accueil/en/content/accueil-en), and 3) Google Books (https://books.google.com/). Searches were run for works published between 1868 and 1920, containing the term 'Protomyxa' and then each item was examined for illustrations of Protomyxa. Approximately 60 works with illustrations were found, including later editions and translations of books. Regardless of the intended audience (scientific or popular), nearly all portrayals were simplification, showing only 1 or a few of the life history stages illustrated in Haeckel's plates shown in Figure 2. Excluding all exact copies of previous illustrations, 20 unique depictions, adaptations of Haeckel's figures, were found and are shown here in Figure 4. 


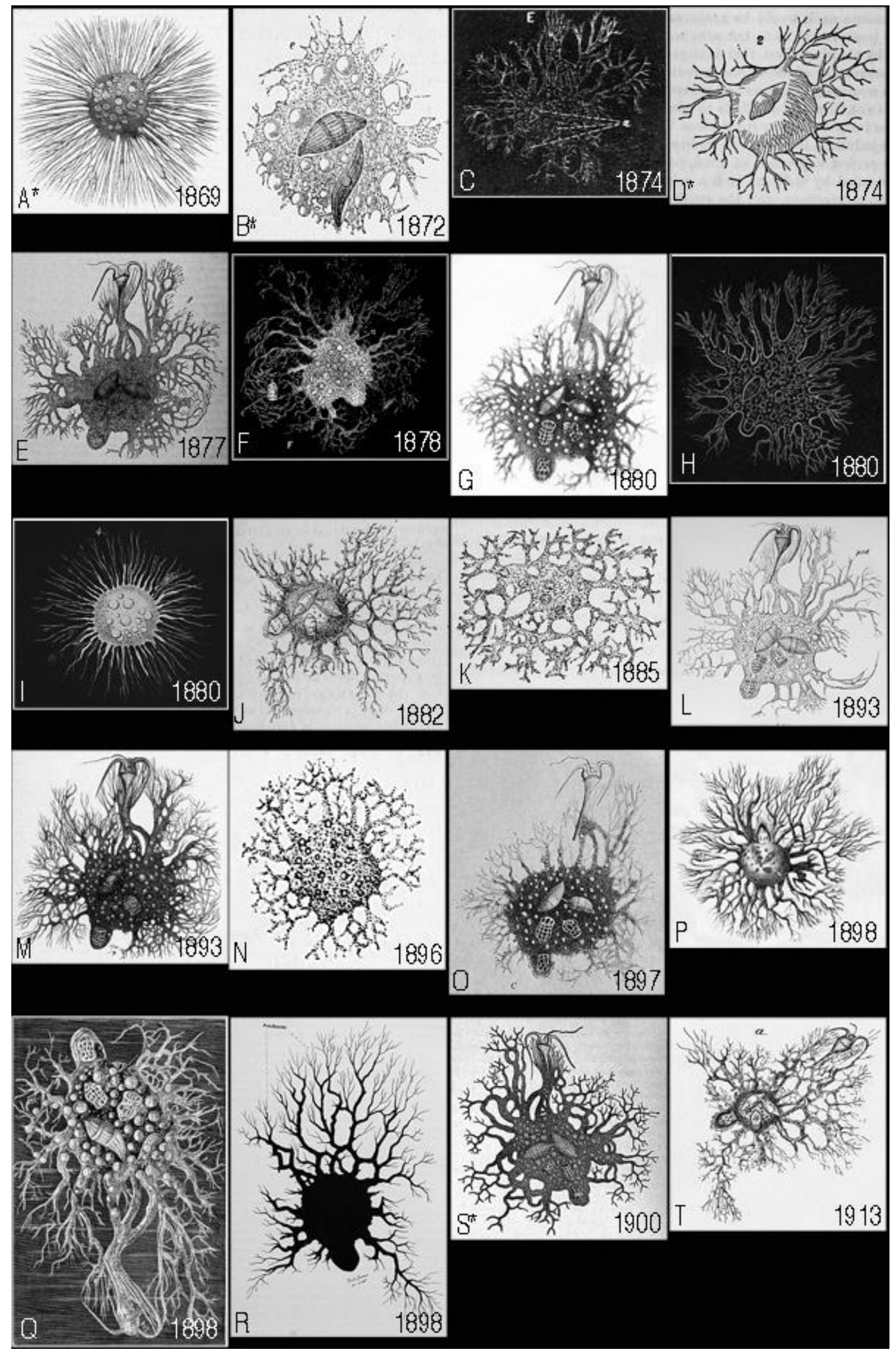

Figure 4. Illustrations of Protomyxa, described as "after Haeckel" in scientific and popular books and articles in chronological order of publication. Letters with asterisks denote appearances in the popular press. A. Brehm 1869; B. Bastian 1872; C. Packard 1874; D. Schneider 1874; E. Huxley 1877; F. Allman 1878; G. Bütschli 1880; H. Nicholson 1880; I. Wallich 1880; J. Lanessan 1882; K. Herdman 1885; L. Parker 1893; M. Retterer 1893; N. Delage 1896; O. Schörter 1897; P. Dubois 1898; Q. Perrier 1898; R. Roule 1898; S. Entry 1900; T. Rhumbler 1913. Note that the most common depiction (15 of the 20) is of the feeding amoeboid stage shown containing recognizable prey remains. 
Casual inspection of the illustrations in figure 4 suffices to conclude that feeding amoeboid stage was the most commonly illustrated form of Protomyxa. It was also the commonly reproduced overall, that is, including all the exact copies of previously published illustrations. Particularly striking is that the illustrations of the feeding amoeboid stage all, except 1 (fig. 4R), showed prey remains clearly recognizable (to those familiar with microscopic organisms as protists, ciliates and dinoflagellates) inside the creature and showed it ensnaring a large living prey item, the common dinoflagellate Ceratium. The illustrations depict predatory behavior, as did the original illustrations. Remarkably, the illustrations show a creature, composed of nothing more than undifferentiated protoplasm, as able to capture highly motile and relatively complex organisms of the marine plankton.

It may appear that accepting simple protoplasm as possibly predacious and able to capture motile prey was unreasonable. However images or other input are not interpreted and processed in a neutral fashion, intuition is present. For example, there is a surprisingly universal "Folk Biology" (e.g. Attran 1998) that perhaps influences intuitive reactions. It is possible then that we are open to scientifically improbable phenomena such as predatory protoplasm. To those familiar with science fiction movies, an amoeboid protoplasm with the ability to consume relatively complex motile prey is not at all surprising. It immediately brings to mind the scenario of the 1958 movie 'The Blob'. In it a small amoeboid creature from another planet arrives on earth via a meteor (recalling Thomson's 1872 hypothesis of the origin of life on earth). The 'Blob' quickly grows into an aggressive, predatory, creature and develops the ability to capture highly motile and complex prey, people, as shown in an illustration from the movie poster (Fig. 5). It proves resistant to all forms of human defense and is eventually neutralized (not destroyed) by being frozen and dropped in the Arctic.

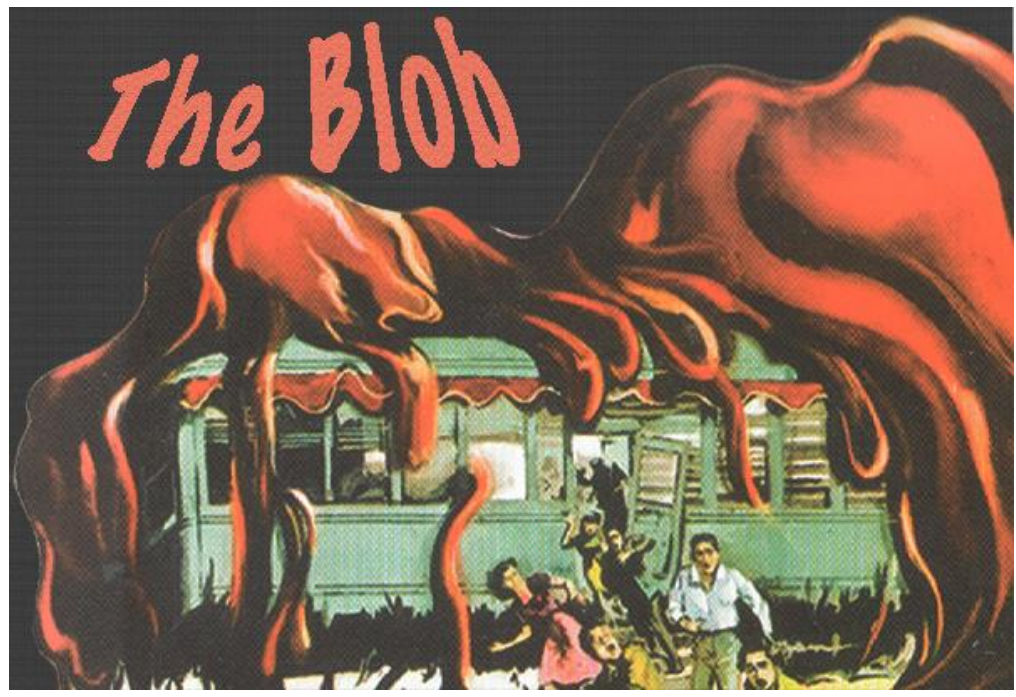

Figure 5. The Blob, a 1958 science fiction movie in which a meteor brings a small creature from outer space that becomes a giant, all-consuming amoeba. The poster shows the aggressive creature capturing motile prey, people. Illustration adapted from WikiMedia.

\section{Characteristics of the primitive}

Depicting "primitive creatures" as aggressive and predatory appears to be common and have a long history. Traditionally, primitive creatures such as dinosaurs have been depicted as aggressive, and predatory, and primitive man as well, as shown in the images in Figure 6. The exact origins of these stereotypes are unclear. For example, with regard to primitive man, the negative views of 'cave-men' have been linked to the emergence of "Social Darwinism" during Haeckel's time which was used to rationalize dominance of industrialized nations over native peoples (e.g., Semonin 1997). Others have argued that our vision of primitive man as an unkempt, grunting, 'wild hairy man' pre-dates the industrial era by far and is common to many cultures (Berman 1999). Regardless 
of the origins of the preconceptions, primitive is associated with aggressive and predaceous behavior. Consequently we may very well be pre-disposed to accept illustrations of a primordial life form, such as Protomyxa as a predator.

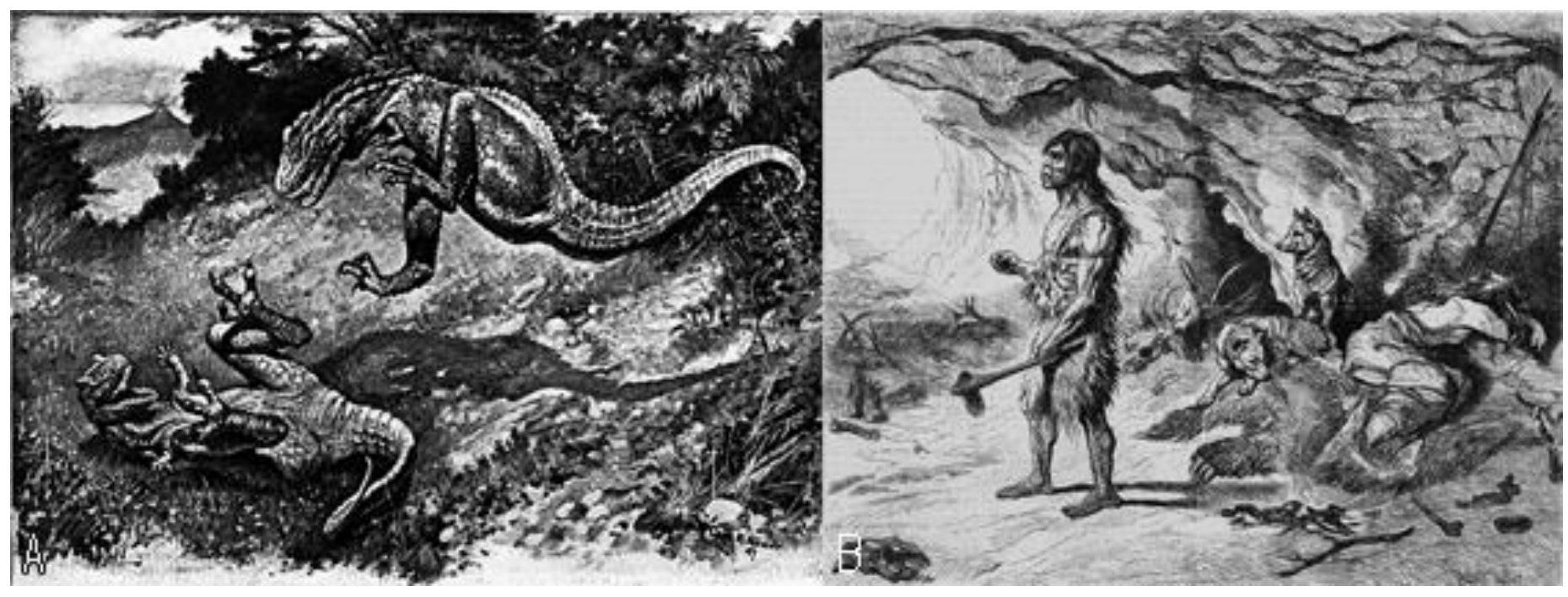

Figure 6. Depictions of dinosaurs (A) and primitive man (B) as aggressive and predatory are familiar sights today and were common during the period when Haeckel's illustrations were being reproduced. In $\boldsymbol{B}$, note the presence of prey remain, bones, in the entrance of the cave. Illustrations from Osborne 1897 (A) and

Anonymous 1873 (B).

\section{Conclusion}

During the short life of the primordial Protomyxa, it was depicted in many different illustrations in a surprisingly consistent manner. The illustrations commonly showed a creature that was predacious, able to ensnare motile prey. The depiction of Protomyxa as a carnivorous creature by Haeckel may have played into our preconceptions concerning "primitivity" and thereby contributed to its rapid and wide-spread, if short-lived, acceptance.

\section{References}

Allman, P. 1878. Recent researches among the some of the more simple sarcode organisms. Linnean Journal, Zoology, 13:385-439.

Anon., 1873. The neanderthal man. Harper's Weekly 17: 617-618

Atran, S. 1998. Folk biology and the anthropology of science: cognitive universals and cultural particulars. Behavioral and Brain Sciences 21: 547-609.

Berman, J.C. 1999. Bad hair days in the Paleolithic : modern (re)constructions of the cave man. American Anthropologist 101:288-304.

Brehm, A.E. 1869. Illustrites Thierleben, Vol 2, Hildenburghhausen, Verlag des Bibliographisches Institutes, 1092 pp

Bastian, C. H. 1872.The beginnings of life; being some account of the nature, modes of origin \& transformation of lower organisms. New York, Appleton, $475 \mathrm{pp}$

Butschli, O. 1880-1882. Protozoa in Broun's Klassen und Ordnungen des Thier-Reichs., vol. 1, Sarkodina und Sporozoa, Leipzig, C.f. Winter'sche Verlagshandlung, 616 pp

Carpenter, W.B. 1883. The microscope and its revelations, 2 vol., New York, Wood \& Company, 388 pp., 354 pp.

Darwin, C. 1859. On the Origin of the Species. Murray, London, $502 \mathrm{pp}$

Darwin Correspondence Project 2020a. "Letter no. 4422," accessed on 24 April 2020, https://www.darwinproject.ac.uk/letter/DCP-LETT-4422.xml 
Darwin Correspondence Project 2020b. "Letter no. 4934," accessed on 24 April 2020, https://www.darwinproject.ac.uk/letter/DCP-LETT-4934.xml

Delage, Y., Héroud, E.J.E. Traité de Zoologie Concréte. Vol. 1, La Cellule et les protozaires. Paris, Beinwald, 582 pp.

Dubois, R. 1898. Leçons de Physiologie Générale et Comparée.Paris, Georhes Carré et C. Naud, Editeurs, 532 pp.

Entry, T.G. 1900. Intelligence in Plants and Animals. New York, Doubleday \& Co., 489 pp

Forbes, E., and Godwin-Austen, R. 1859. The Natural History of the European Seas. John Van Voorst, London, 306 pp.

Haeckel, E. 1863. Ueber die Entwickelungsgeschichte Darwins. Amtlicher Bericht über die 38. Versammlung Deutscher Naturforscher und Ärzte in Stettin, 17-30.

Haeckel E. 1865. Über den Sarcodekörper der Rhizopoden. Z. Wiss. Zool. 15:342-370

Haeckel, E. 1866. Generelle morphologie der organismen. Allgemeine grundzüge der organischen formenwissenschaft, mechanisch begründet durch die von Charles Darwin reformirte descendenztheorie, Berlin, G. Reimer, vol. 1574 pp, vol. 2462 pp.

Haeckel, E. 1868. Monographie der Moneren. Jena Z Med Naturwiss 4:64-137

Haeckel, E. 1869. Monograph of monera by Ernst Haeckel. Quar J. Micros Sci 9:27-42, 113-134, 219-232, 327-342.

Haeckel, E. 1873. Natürliche Schöpfungsgeschichte. Gemeinverständliche wissenschaftliche Vorträge über die Entwickelungslehre im Allgemeinen und diejenige von Darwin, Goethe und Lamarck und Besonderen. 3rd ed, G. Reimer, Berlin, $568 \mathrm{p}$

Haeckek, E. 1876. The history of creation; or, The development of the earth and its inhabitants by the action of natural causes : a popular exposition of the doctrine of evolution in general, and of that of Darwin, Goethe and Lamarck in particular. New York, Appelton, 2 vol., 374 pp, 408 pp

Haeckek, E. 1877. Histoire de la création des êtres organisés d'après les lois naturelles : conférences scientifiques sur la doctrine de l'évolution en général et celle de Darwin, Goethe et Lamarck en particulier. Paris, C. Reinwald et Cie., $684 \mathrm{pp}$

Herdman, W.A. 1885. A Phylogenetic Classification of Animals (for the use of students). London, Macmillian and Co, $76 \mathrm{pp}$.

Huxley, T.H., 1877. A Manual of the Anatomy of Invertebrated Animals. London, J. \& A. Churchill, 596 pp.

Lanessan, J.-L. 1882. Traité de Zoologie, Paris, O. Doin, 336 pp.

Nicholson, H.A. 1880. A manual of Zoology, 6th ed. Edinburgh, William Blackwood and Sons, 847 pp.

Osborn, H.F. 1897. A great naturalist. Edward Drinker Cope. Century Magazine 55:10-15.

Packard, A.S. jr. 1874. Life histories of the Protoza. American Naturalist, 8:728-748.

Parker, T.J. 1893. Lessons in Elementary Biology. London, Macmillian and Co., 408 pp.

Pasteur, L. 1861. Mémoire sur les corpuscules organisés qui existent dans l'atmosphére, examen de la doctrine des généerations spontanées. Annales des Sciences Naturelles, Ser. 4, Zoologie, 16: 5-98.

Perrier, E. 1898. Les Colonies Animales et la Formation des Organismes. Paris, Masson et Cie., 797 pp.

Retterer, E. 1893. Anatomie et Physiologie Animales. Paris, Librarie Hachette et Cie., 584 pp.

Rhumbler, L. 1913. Die Foraminiferen (Thalamophoren) der Plankton- Ex- pedition, Zweiter Teil, Systematik: Arrhabdammidia, Arammodisclidia und Arnodosammidia. Ergebnisse der Plankton- Expedition der Humboldt, Stiftung, Kiel u. Leipzig, 3, 332-476.

Riechert, C. 1863. über die Bewegungserscheinungen an den Scheinfüfsen der Polythalamien, insbesondere über die sogenannte Körnechenbewegung und über das angebliche Zusammenfliefsen der Scheinfüfse. Monatsberichte der Königlichen Preussische Akademie des Wissenschaften zu Berlin. Aus dem Jahre 1862, 406-426.

Roule, R. 1898. L'Anatomie Comparée des animaux basée sur l'embryologie. Paris, Masson, 1971 pp,

Schneider, A. 1874. Häckel's moners. Popular Science Monthly, 4: 181-183. 
Schörter, J. 1897. Anhang. Die mit den Myxomyceten nächstverwandten Organismen. in Engler, A, Krause, K., Pilger, R.K.F., Prantl, K. (eds), Die Natürlichen Pflanzenfamilien nebst ihren Gattungen und wichtigeren Arten, insbesondere den Nutzpflanzen, unter Mitwirkung zahlreicher hervorragender Fachgelehrten begründet. Teil 1, Abt. 1, pp 36-41.

Semonin, P. 1997. Empire and extinction: the dinosaur as a metaphor for dominance in prehistoric nature. Leonardo 30:171-178.

Stijnman, A. 2012. Engraving and Etching 1400-2000: A History of the

Development of Manual Intaglio Printmaking Processes. Houten, Hes \& Degraaf, 672 pp.

Thomson, W. 1872. Address of Sir William Thomson, Knt., LL.D., F.R.S, President. Report of the Forty-first meeting of the British Association for the Advancement of Science held in Edinburgh in August 1871: lxxxiv- cv.

Wallich, S.M. 1880. The threshold of evolution. Popular Science Review, 4:143-155. 